\title{
The effect of accessibility and value addition on the costs of controlling invasive alien plants in South Africa: A three-species system dynamics model in the fynbos and grassland biomes
}

\section{Douglas J Crookes , James N Blignaut \& David C Le Maitre}

To cite this article: Douglas J Crookes, James N Blignaut \& David C Le Maitre (2020) The effect of accessibility and value addition on the costs of controlling invasive alien plants in South Africa: A three-species system dynamics model in the fynbos and grassland biomes, Southern Forests: a Journal of Forest Science, 82:2, 125-134, DOI: 10.2989/20702620.2019.1686685

To link to this article: https://doi.org/10.2989/20702620.2019.1686685

曲 Published online: 03 Nov 2020.

Submit your article to this journal $\pi$

Џ Article views: 9

Q View related articles ¿ك

View Crossmark data $[7$ 


\title{
The effect of accessibility and value addition on the costs of controlling invasive alien plants in South Africa: A three-species system dynamics model in the fynbos and grassland biomes
}

\author{
Douglas J Crookes $^{1 *}(\mathbb{D})$, James N Blignaut ${ }^{2,3}$ (D) and David C Le Maitre ${ }^{4,5}$ (D) \\ 1 School of Public Leadership, Stellenbosch University, South Africa \\ 2 School of Public Leadership, Stellenbosch University, South Africa \\ ${ }^{3}$ South African Environmental Observation Network, Pretoria, South Africa \\ 4 Smart Places, Council of Industrial and Scientific Research (CSIR), Stellenbosch, South Africa \\ ${ }^{5}$ Centre for Invasion Biology, Department of Botany and Zoology, Stellenbosch University, South Africa \\ ${ }^{*}$ Corresponding author: douglascrookes@gmail.com
}

\begin{abstract}
We developed a two-biome (grasslands and fynbos) system dynamics model simulating invasions of three invasive alien plant species - black wattle (Acacia mearnsii) and two pine species (Pinus patula and Pinus pinaster) - and some of the consequences. The model considers three components: invasion dynamics; revenue from the sale of woody products derived from clearing invasive alien plants; and a coefficient that models the effect of increased accessibility to invaded areas. The model shows that increasing the returns on value added products (VAPs) from invasive alien plants (IAPs) by between $70 \%$ and $130 \%$ results in positive nett present values (NPVs) of R2.7 million for $P$. patula, R151.7 million for $P$. pinaster and R115.9 million for $A$. mearnsii (1996 base year). At the same time, the invasion of these species is reduced dramatically by 2025 . The results show that there is much scope, and indeed a clear requirement, for improved returns on investment from harvesting these species through increasing the returns from VAPs. However, accessibility to invaded areas would need to be increased for positive nett gains in water yields and other returns to be maximised.
\end{abstract}

Keywords: A. mearnsii, clearing, P. patula, $P$. pinaster, value-added products

Introduction

Clearing of invasive alien plants (IAPs) is expensive (Marais and Wannenburgh 2008), often reducing the motivation to do so, despite the strong link between IAPs and the loss of ecosystem services (Gaertner et al. 2012). The clearing of IAPs has several benefits, including job creation, increased water yields and the possibility of a payments for ecosystem services mechanism whereby benefits from clearing IAPs can be monetised (Turpie et al. 2008). The primary mechanism for clearing IAPs is currently the Working for Water (WfW) programme which is a government funded programme launched in 1995 (Van Wilgen et al. 2012). Clearing of IAPS opens up the possibility of selling several value added products (VAPs), so called since they enable financial compensation for clearing to be obtained (Mudavanhu et al. 2016; Vundla et al. 2016; Nkambule et al. 2017), potentially allowing IAP clearing to 'pay for itself' or, at the very least, to significantly reduce the costs. Crookes and Blignaut (2019) reviewed 19 case studies where IAP clearing was being done. They found that this process does pay, with returns from clearing ranging between $\$ 1.32$ and $\$ 1552.80$ ha $^{-1}$. Only one of the case studies reviewed produced negative returns from clearing. Although VAPs are relatively well studied in the savannah biomes (Ballance et al. 2001), it is less well studied in the grassland and fynbos biomes of South Africa, hence the focus of this paper on these two biomes.

An aspect of IAP control that has not been well studied is the issue of accessibility, in particular the ability to reach and harvest them, especially since many IAPs are on mountain slopes or in riparian areas. Le Maitre et al. (2016) estimated that at least $20 \%$ of Acacia mearnsii De Wild invasions are in riparian areas, especially in the grassland biome, while most invasions of Pinus spp. are non-riparian and in mountainous areas according to Richardson et al. (1997). Accessibility is likely to become an increasing problem for clearing operations, because easy to reach areas are cleared first, leaving less accessible areas invaded by IAPs. This is the case in the fynbos biomes of Outeniqua, Wilderness and Knysna, as noted by Roura-Pascual et al. (2009). Accessibility is difficult to model as it is a function of topography, soil characteristics and rockiness which can only be estimated using detailed spatial data (McConnachie et al. 2015). Nevertheless, we believe that it is important to attempt to develop a better understanding of the importance of accessibility in IAP management.

This study models three IAP species in South Africa: one 
acacia species (black wattle (Acacia mearnsii)) and two Pinus species (patula pine (Pinus patula Schiede ex Schltdl. \& Cham)) and maritime or cluster pine (Pinus pinaster Aiton)). Acacia mearnsii was chosen since it is one of the most prevalent invaders in terms of area in the grassland and fynbos biomes of South Africa (Henderson 2007; Le Maitre et al. 2013), while $P$. pinaster is the most prevalent of the Pinus species invading the fynbos biome in terms of area invaded (Henderson 2007). Furthermore, $P$. patula is the most prevalent of the Pinus species invading the grassland biome (Henderson 2007).

The earliest system dynamics model of IAP management in South Africa was developed by Higgins et al. (1997) and simulates the costs and benefits of clearing IAPs in the fynbos biome. Our study extends this analysis to the grassland biome which contains most of the strategic water source areas, from the Amatole through to the Soutpansberg (Blignaut et al. 2010; WWF 2013). Van Wilgen et al. (2008) modelled the economic implications of the spread of IAPs for water resources, rangeland productivity and biodiversity at the biome level for South Africa, but did not assess scenarios. Crookes et al. (2013) modelled the costs and benefits of different control measures (both active and passive restoration) in case studies in several different regions in South Africa. They did not attempt to aggregate the case studies to a biome level, whereas our study undertakes a biome level assessment. Our study also includes VAPs from IAPs. Other case study models include Morokong et al. (2016) on the impacts of clearing IAPs on water infrastructure protection, Mudavanhu et al. (2016) on clearing for feedstock for electricity generation, and Vundla et al. (2016) on VAPs as a means of co-financing IAP clearing. All these studies showed the positive benefits that could be derived from IAP clearing but were done at an individual case study level and not at a national or biome level.

\section{Invasive alien plants in the study}

Although South Africa has many IAPs, the black wattle (A. mearnsii) from Australia is significant since it is very widespread and abundant in most of the biomes in the country (Henderson 2001; Nel et al. 2004). It also has important economic benefits through sales of bark for tannins and woodchips (pulp wood) and as a source of fuelwood and charcoal (De Wit et al. 2001; Shackleton et al. 2007). The cluster pine ( $P$. pinaster) originates from Europe and is not currently utilised commercially in South Africa (Hoffmann et al. 2011). In contrast, the patula pine ( $P$. patula) originates from North America and is grown commercially by the forestry industry in South Africa (Hoffman et al. 2011). Approximately half of all commercial forestry pine plantations are $P$. patula (Nyoka 2003). All three species are classified as Category 2 invaders in South Africa so they can only be grown in pre-demarcated areas (Henderson 2001) and, where they are invading, all three species have negative environmental impacts including greater water use than natural vegetation (Dye and Versfeld 2007). Pinus pinaster and $P$. patula occur in geographically distinct areas (Figure 1), with $97 \%$ of $P$. pinaster invasions occurring in the fynbos biome (Moran et al. 2000), and $P$. patula in the moist grassland regions (Richardson et al. 1997).

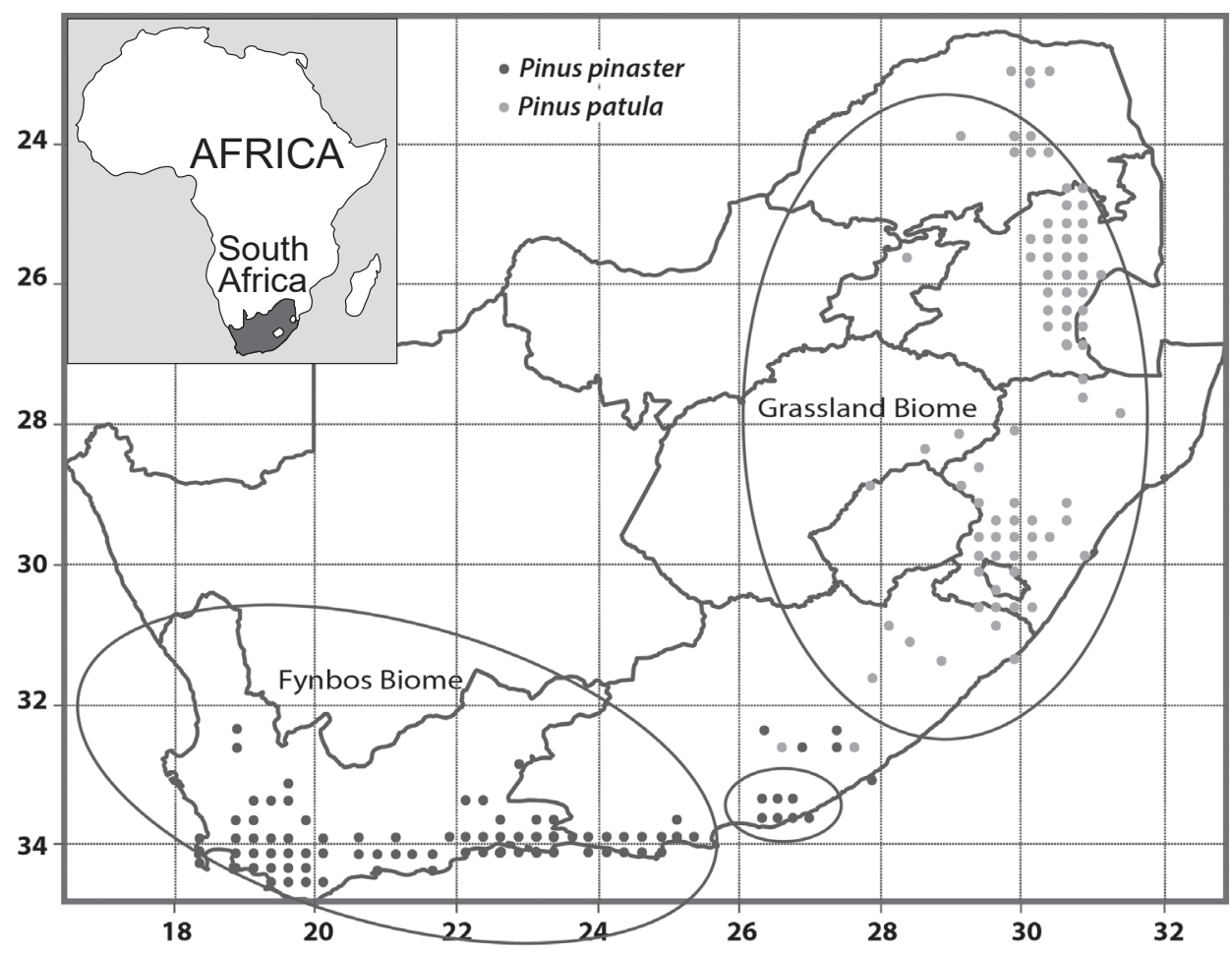

Figure 1: Distribution of invasive Pinus pinaster and Pinus patula in South Africa. Sources: Based on Henderson (2001); Mucina and Rutherford (2006) 


\section{Research method}

\section{System dynamics model}

System dynamics models of IAP growth and clearing are well established in the literature (e.g., Higgins et al. 1997; Gaertner et al. 2014; Mudavanhu et al. 2017a; Vundla et al. 2017). Most of these models, however, do not model species interactions using a Lotka-Volterra formulation. The standard Lotka-Volterra system is a system of differential equations (e.g., Bjørndal and Conrad 1987):

$$
\begin{aligned}
& \frac{d x}{d t}=r x\left(1-\frac{x}{k}\right)-q E x \\
& \frac{d E}{d t}=\delta(p q E x-c E)
\end{aligned}
$$

Where $d x / d t$ is the logistic equation which is a function of the population $x$, the growth rate $r$ and the carrying capacity $k$. The harvest function $h=q E x$, where $q$ is the catchability coefficient and $E$ is the harvesting effort. The second differential equation shows the dynamics of harvesting effort $E$, which is a function of an adjustment parameter $\delta$, the price $p$ and the cost per unit effort $c$. In our model, $x$ is the spread of IAPs and $q$ is the accessibility coefficient. We see that accessibility relates to the efficiency of harvesting, since an improvement in efficiency improves the yield of the product per unit effort. So, an improvement in accessibility improves the rate of harvesting and in our model, effort becomes the clearing effort. Prices are the values from the sale of VAPs, and the costs are the costs of clearing. The precise model equations are elaborated in a subsequent section.

The use of the Lotka-Volterra formulation in system dynamics modelling was pioneered by Swart and Hearne (1989) and further developed by Swart (1990). The Lotka-Volterra formulation in system dynamics has been extensively used in fisheries (Crookes 2016), wildlife (Crookes 2017), industry (Crookes and Blignaut 2016) and in dam construction (Crookes 2018). This would be the first time such a model is used in connection with IAP control, at least for South African IAPs. Grimsrud et al. (2008) developed a very similar model to ours in New Mexico, however, they modelled interactions between a grass and an invasive weed rather than invasive trees, and the profitability of control is in relation to the sale of cattle products rather than timber VAPs.

Although the model is also known as the predator-prey model, a predator-prey relationship is not required in the biological sense nor does it matter which component is the predator and which is the prey. For example, Dendrinos and Mullally (1981) developed an urban dynamics model, defining the urban population as the predator and per capita income as the prey. For a similar urban dynamics application, Orishimo (1987) defined population as the prey and land price as the predator. However, we do believe that a plausible predator-prey relationship does exist in the case of our IAP model. There is strong precedent in using predator-prey models in IAP species interactions (e.g., Osunkoya et al. 2005), however, none have focussed on the control effort being the predator. At the same time, though, Fowler and Pease (2010) found that modifications to the logistic growth function for plant species performed better than the pure logistic function. Here, we also modify the logistic growth function to take into consideration different density dependent terms. The precise functional relationship is elaborated on in a subsequent section.

The Lotka-Volterra formulation is used to understand the effect of accessibility on harvesting. In the system the resources are the IAPs which are influenced by the control effort. The model assesses the effects of changes in the clearing budget on control effort, which in turn affects how much of the IAP species are harvested. We model our three IAP species using the Lotka-Volterra formulation, stocks and flows, systems modelling approach (see Figure 2, only wattle shown). The model also comprises two biomes: the fynbos and grassland biomes (the model appears to be the same for both, however, the underlying parameter values for each biome differ). Control effort is the predator and the IAP resource is the prey.

\section{IAP growth}

A logistic model is used to estimate the change in the spread of IAPs over time based on the fact that the expansion of invasions typically follows a sigmoidal form (Drake et al. 1988; Hengeveld 1989; Le Maitre et al. 2002; Cullis et al. 2007) (Figures 2 and 3). The logistic model assumes density dependence in the spread rates of the IAPs with slow expansion at low densities (based on spread) during establishment and slowing again as invaders occupy the invadable area. However, a second aspect that is important is the increase in the density of IAPs related to condensed area invaded (up to a maximum of $100 \%$ ) (Moody and Mack 1988). This does not follow for a density dependent trajectory, but rather an exponential population growth until the maximum of density is achieved (i.e., 100\% canopy cover). Therefore, IAP growth in the model incorporates both a density dependent term related to spread and an exponential density increase which is expressed as the condensed area.

\section{Model parameters}

The values of the parameters in the model are derived primarily from the literature (Table 1). The carrying capacity for each species is the maximum condensed hectares it could occupy (i.e., the hectares it could cover at $100 \%$ density). This was estimated for each of the species in each biome from the remaining natural vegetation, derived from the land cover in 2013-2014 (GTI 2015), which is potentially invadable based on the potential distributions for the respective species, as modelled by Rouget et al. (2004).

We planned to parameterise the rate of spread by comparing the data from the 1996 survey (Versfeld et al. 1998) with the 2007 National Invasive Alien Plant Survey (Kotzé et al. 2010). The data from the two surveys are difficult to compare though because they were obtained in very different ways. The 1996 data set was compiled from a range of sources and involved a range of methods, from detailed field mapping to desktop and workshop-based mapping (Versfeld et al. 1998). The 2007 data set was obtained from aerial surveys involving 1 ha random samples within extensive homogeneous mapping units at quite a low sampling intensity (Kotzé 


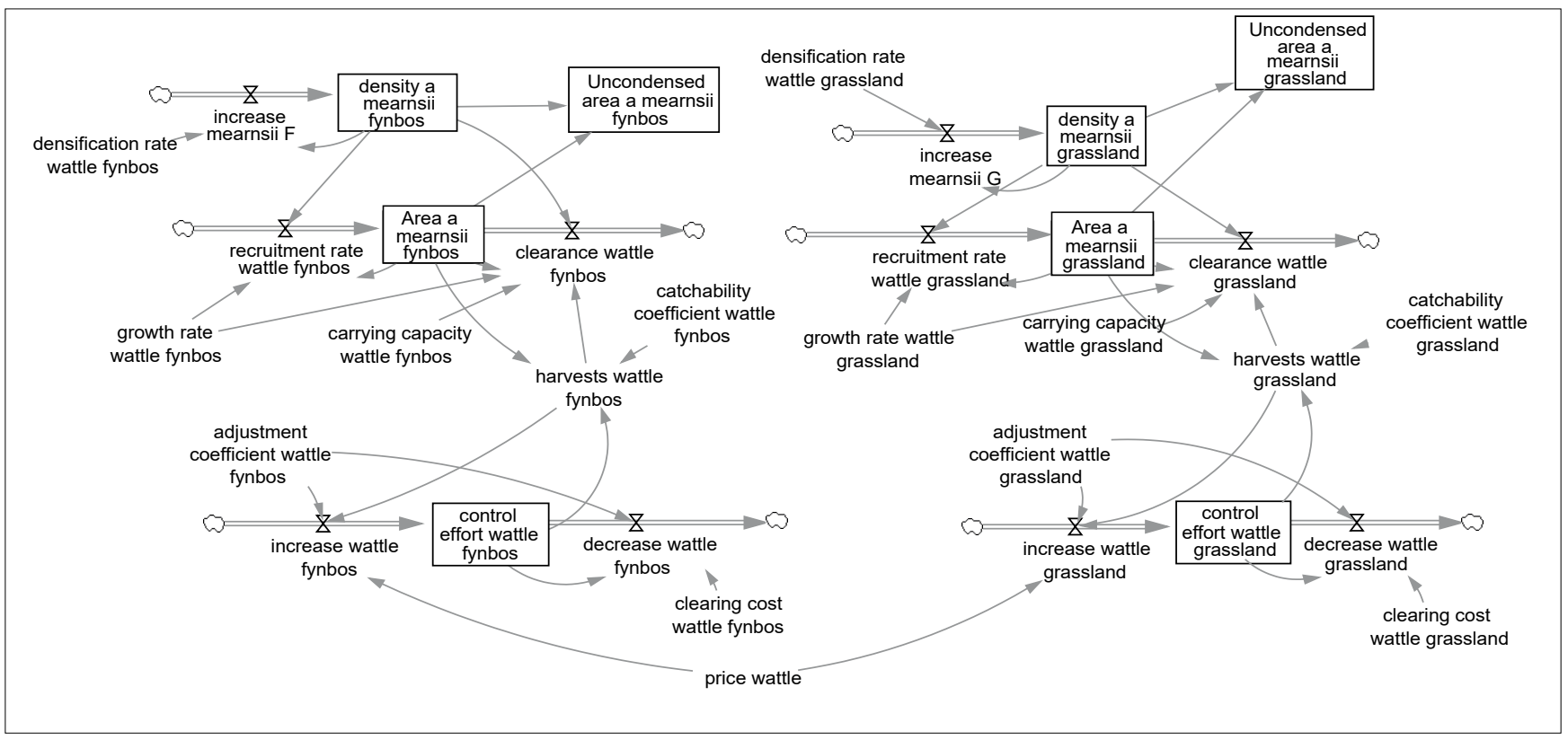

Figure 2: Stock-flow diagram of the A. mearnsii sub-model. The stock flow diagram shows how the components of the model interact. The arrows indicate directions of causality. Behind each component is an equation or parameter value. Parameters used in the model are given in Table 1.

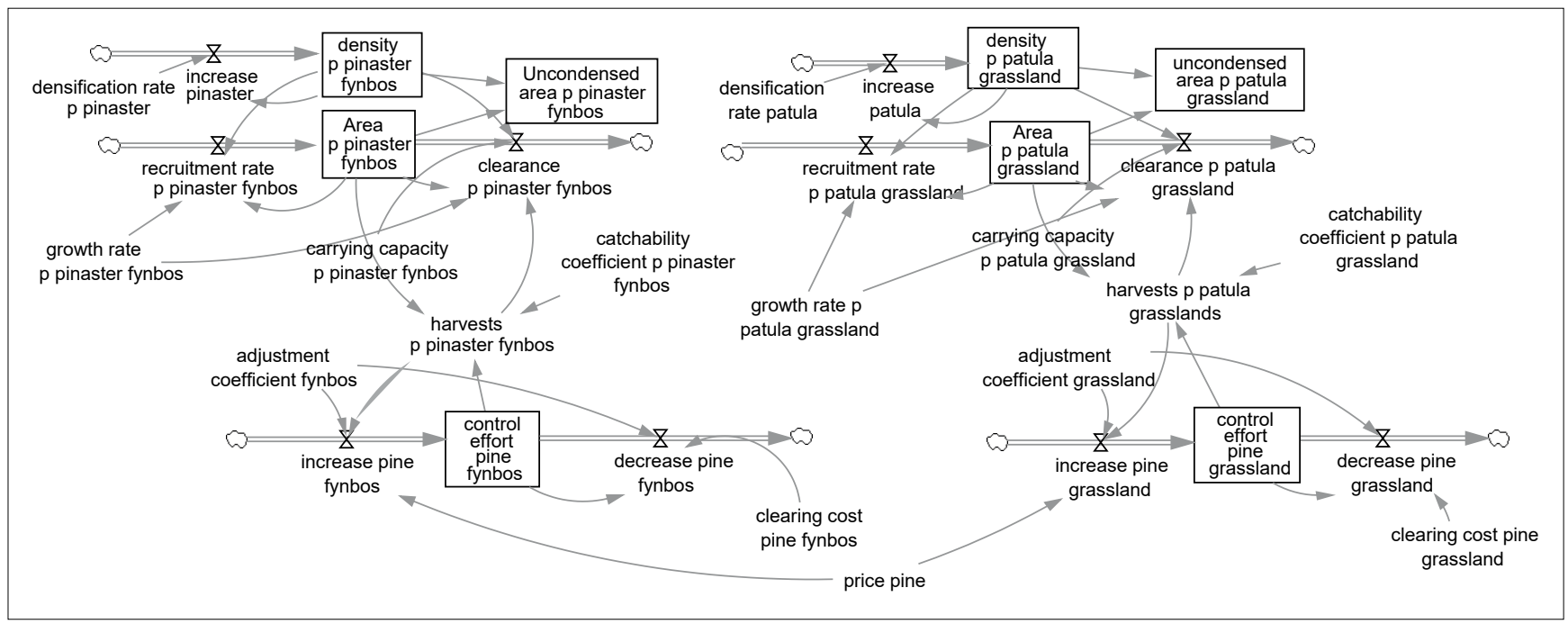

Figure 3: Stock-flow diagram of the Pinus spp sub-model. The stock flow diagram shows how the components of the model interact. The arrows indicate directions of causality. Behind each component is an equation or parameter value. Parameters used in the model are given in Table 1.

et al. 2010). Van Wilgen et al. (2012) attempted a direct comparison but found, for example, an apparently substantial decrease in the extent of $A$. mearnsii from 1996 to 2007 in the fynbos biome, a decrease which could not be explained by control operations. Nor is this decrease consistent with its historical success as an invader and the very substantial increases in the extent of $A$. mearnsii and allies ( $A$. dealbata, $A$. decurrens) in the grassland and savannah biomes during the same period. The substantial increase in Acacia invasions the grassland and savannah biomes is partly due to poor coverage of these biomes in the Eastern Cape in the 1996 data set (Le Maitre et al. 2016). However, what we did find was that if we excluded the very extensive areas of low $(<5 \%)$ and very low $(<0.1 \%)$ density invasions in the 1996 data set then the 1996 invasions were more comparable with the 2007 ones, allowing for spread rates of about $5 \%$. The rationale for the exclusion of low 
Table 1: Parameters used in the model

\begin{tabular}{|c|c|c|c|c|}
\hline Symbol & Parameter & Value & Units & Description \\
\hline$n^{\mathrm{F}}$ & Adjustment coefficient fynbos $^{\dagger}$ & $1.0 \times 10^{-5}$ & hectare/rand & $\begin{array}{l}\text { Relates to the rate at which control effort in the fynbos } \\
\text { biome responds to changes in the price of IAPs and } \\
\text { clearing costs }\end{array}$ \\
\hline$n^{G}$ & Adjustment coefficient grassland ${ }^{\dagger}$ & $1.0 \times 10^{-5}$ & hectare/rand & $\begin{array}{l}\text { Relates to the rate at which control effort in the grassland } \\
\text { biome responds to changes in the price of IAPs and } \\
\text { clearing costs }\end{array}$ \\
\hline$k_{1}^{F}$ & Carrying capacity A. mearnsii fynbos ${ }^{\dagger}$ & 2639423 & hectare & $\begin{array}{l}\text { Maximum condensed area of } A \text {. mearnsii in the fynbos } \\
\text { biome }\end{array}$ \\
\hline$k_{2}^{F}$ & Carrying capacity $P$. pinaster fynbos ${ }^{\dagger}$ & 2800875 & hectare & $\begin{array}{l}\text { Maximum condensed area of } P \text {. pinaster in the fynbos } \\
\text { biome }\end{array}$ \\
\hline$k_{1}^{G}$ & Carrying capacity A. mearnsii grassland ${ }^{\dagger}$ & 9813395 & hectare & $\begin{array}{l}\text { Maximum condensed area of } A \text {. mearnsii in the grassland } \\
\text { biome }\end{array}$ \\
\hline$k_{2}^{G}$ & Carrying capacity $P$. patula grassland ${ }^{\dagger}$ & 5309521 & hectare & $\begin{array}{l}\text { Maximum condensed area of } P \text {. patula in the grassland } \\
\text { biome }\end{array}$ \\
\hline$q_{2}^{\mathrm{F}}$ & Accessibility coefficient $P$. pinaster fynbos ${ }^{\dagger}$ & $1.2 \times 10^{-5}$ & 1/(hectare $\times$ year) & $\begin{array}{l}\text { Indicates how easy it is to find, reach and harvest pine in } \\
\text { the fynbos biome }\end{array}$ \\
\hline$q_{2}^{G}$ & Accessibility coefficient $P$. patula grassland ${ }^{\dagger}$ & $1.1 \times 10^{-5}$ & $1 /$ (hectare $\times$ year $)$ & $\begin{array}{l}\text { Indicates how easy it is to find, reach and harvest pine in } \\
\text { the grassland biome }\end{array}$ \\
\hline$q_{1}^{\mathrm{F}}$ & Accessibility coefficient $A$. mearnsii fynbos ${ }^{\dagger}$ & $1.1 \times 10^{-4}$ & $1 /$ (hectare $\times$ year $)$ & $\begin{array}{l}\text { Indicates how easy it is to find, reach and harvest } \\
\text { A. mearnsii in the fynbos biome }\end{array}$ \\
\hline$q_{1}^{\mathrm{G}}$ & Accessibility coefficient A. mearnsii grassland ${ }^{\dagger}$ & $1.0 \times 10^{-6}$ & 1/(hectare $\times$ year) & $\begin{array}{l}\text { Indicates how easy it is to find, reach and harvest } \\
\text { A. mearnsii in the grassland biome }\end{array}$ \\
\hline$p_{1}$ & Price of pine ${ }^{\dagger}$ & 7300 & rand/hectare & Value of timber sales \\
\hline$C^{\mathrm{F}}$ & Clearing cost fynbos $\ddagger$ & 4576.7 & rand/(hectare $\times$ year) & Total cost of eradicating wattle and pines in the fynbos biome \\
\hline$c^{G}$ & Clearing cost grassland $\ddagger$ & 3417.8 & rand/(hectare $\times$ year) & Total cost of eradicating wattle and pines in the grassland biome \\
\hline$p_{2}$ & Price of wattle ${ }^{\dagger}$ & 1800 & rand/hectare & Value of firewood sales \\
\hline$r_{2}^{F}$ & Growth rate $P$. pinaster in fynbos§ & 0.156 & 1/year & Maximum intrinsic growth rate of $P$. pinaster in fynbos biome \\
\hline$r_{2}^{G}$ & Growth rate $P$. patula grassland $\S$ & 0.156 & 1/year & Maximum intrinsic growth rate of $P$. patula in grassland biome \\
\hline$r_{1}^{F}$ & Growth rate $A$. mearnsii fynbos $§$ & 0.1 & 1/year & Maximum intrinsic growth rate of $A$. mearnsii in fynbos biome \\
\hline$r_{1}^{G}$ & Growth rate $A$. mearnsii grassland§ & 0.1 & 1/year & Maximum intrinsic growth rate of $A$. mearnsii in grassland biome \\
\hline$d_{1}^{F}$ & Densification rate $A$. mearnsii fynbos ${ }^{\dagger}$ & 0.2 & 1/year & Rate at which $A$. mearnsii in fynbos biome densifies \\
\hline$d_{1}^{G}$ & Densification rate $A$. mearnsii grassland ${ }^{\dagger}$ & 0.082 & 1/year & Rate at which $A$. mearnsii in the grassland biome densifies \\
\hline$d_{2}^{F}$ & Densification rate $P$. pinaster fynbos ${ }^{\dagger}$ & 0.069 & 1/year & Rate at which $P$. pinaster in the fynbos biome densifies \\
\hline$d_{2}^{G}$ & Densification rate $P$. patula grassland ${ }^{\dagger}$ & 0.009 & 1/year & Rate at which $P$. patula in the grassland biome densifies \\
\hline$x_{1}^{F}$ & Initial area $A$. mearnsii fynbos $\pi$ & 103626 & hectares & Area in 1996 (uncondensed hectares), omitting densities $<5 \%$ \\
\hline$x_{1}^{G}$ & Initial area A. mearnsii grassland $\pi$ & 91476 & hectares & Area in 1996 (uncondensed hectares), omitting densities $<5 \%$ \\
\hline$x_{2}^{\mathrm{F}}$ & Initial area $P$. pinaster fynbos $\pi$ & 92696 & hectares & Area in 1996 (uncondensed hectares), omitting densities $<5 \%$ \\
\hline$x_{2}^{G}$ & Initial area $P$. patula grassland $\pi$ & 1048 & hectares & Density in 1996, omitting densities < $5 \%$ \\
\hline$D_{1}^{\mathrm{F}}$ & Initial density A. mearnsii fynbos $\pi$ & 22.9 & Dimensionless (\%) & Density in 1996, omitting densities < $<\%$ \\
\hline$D_{1}^{G}$ & Initial density A. mearnsii grasslandף & 26.58 & Dimensionless (\%) & Density in 1996, omitting densities < $5 \%$ \\
\hline$D_{2}^{\mathrm{F}}$ & Initial density $P$. pinaster fynbos $₫$ & 21.4 & Dimensionless (\%) & Density in 1996, omitting densities < $5 \%$ \\
\hline$D_{2}^{\mathrm{G}}$ & Initial density $P$. patula grassland $\pi$ & 30.71 & Dimensionless (\%) & Density in 1996, omitting densities < $<\%$ \\
\hline
\end{tabular}

Note: For more information on the variables see the text.

Source: † Model. Parameter derived from calibrating the model with the historical data; $\ddagger$ Calculated from Van Wilgen et al. (2012);

$\S$ Van Wilgen and Le Maitre (2013); ^ Calculation from data in Versfeld et al. (1998). 
density classes is the very low probability of accurately detecting and quantifying such sparse invasions given the low sampling intensity of the 2007 survey. For this analysis we have used the adjusted 1996 extent of the invasions for the initial invaded areas and densities for the model (Table 1).

The rest of the parameters are obtained through calibration with the historical data (clearing effort and IAP area). As far as the historical data are concerned, these were obtained or calculated from several different sources. Areas cleared permanently per biome for 1996 and 2008 were obtained from Van Wilgen et al. (2012) or calculated from data in Kotzé et al. (2010). The study also utilised Working for Water data on area cleared per province from 1996 to 2008 (IDC 2011), which needed to be apportioned by species cleared and biome. The apportioning by biome was done by assuming that the fynbos biome was essentially confined to the Western Cape, while the grassland biome fell within the Eastern Cape, Gauteng, KwaZulu-Natal, Limpopo, Mpumalanga and Free State provinces. The proportion of clearing that was wattles and pines was then extracted using the share of these species in each biome within these provinces from the Kotzé et al. (2010) data.

\section{Model equations}

Condensed hectares invaded $(x)$ is an increasing function of two variables:

$$
x=F(\alpha, \delta)
$$

where $\alpha$ is the total area invaded, and $\delta$ is the density of the invasions in the area. Each of these functions evolve differently over time: are a invaded increases following a sigmoid function, initially increasing rapidly but then decreasing as the invaded area approaches $100 \%$ of the available area, whereas density follows an exponential growth curve to its maximum (Figure 4).

We therefore postulated, for a species $j$, that growth of condensed hectares (spread at $100 \%$ density of IAPs) invaded $(x)$ will occur according to the following growth function:

$$
\frac{d x_{j}^{i}}{d t}=r_{j}^{i} d_{j}^{i} D_{j}^{i} x_{j}^{i}\left(1-\frac{x_{j}^{i}}{k_{j}^{i}}\right)-q_{j}^{i} E^{i} x_{j}^{i}
$$

where $i$ is the biome: $\mathrm{F}=$ Fynbos, $\mathrm{G}=$ Grassland, and $j$ is the species: $1=$ wattle and $2=$ pine. $D_{j}^{i}$ is the density of species $j$ in biome $i$ and $d_{j}^{i}$ is the densification rate, $r_{j}^{i}$ is the spread rate of species $j$ in biome $i$, and $q_{j}^{i}$ is the accessibility coefficient of species $j$ in biome $i$.

Control effort grows according to the following differential equation:

$$
\frac{d E_{j}^{i}}{d t}=n_{i} E_{j}^{i}\left(p_{j} q_{j}^{i} x_{j}^{i}-c_{i}\right)
$$

where $i=$ Fynbos $(\mathrm{F})$, Grassland $(\mathrm{G})$ and $j=$ wattle (1), pine (2). $P_{j}$ is the price of VAPs of species $j$ and $c_{i}$ is the cost of clearing biome $i$. The descriptions and values of the parameters are further elaborated in Table 1.

\section{Model validation}

An advantage of using system dynamics tools for these types of models is that confidence in the model may be improved by conducting a range of validation tests. For example, the software enables several unit checks to
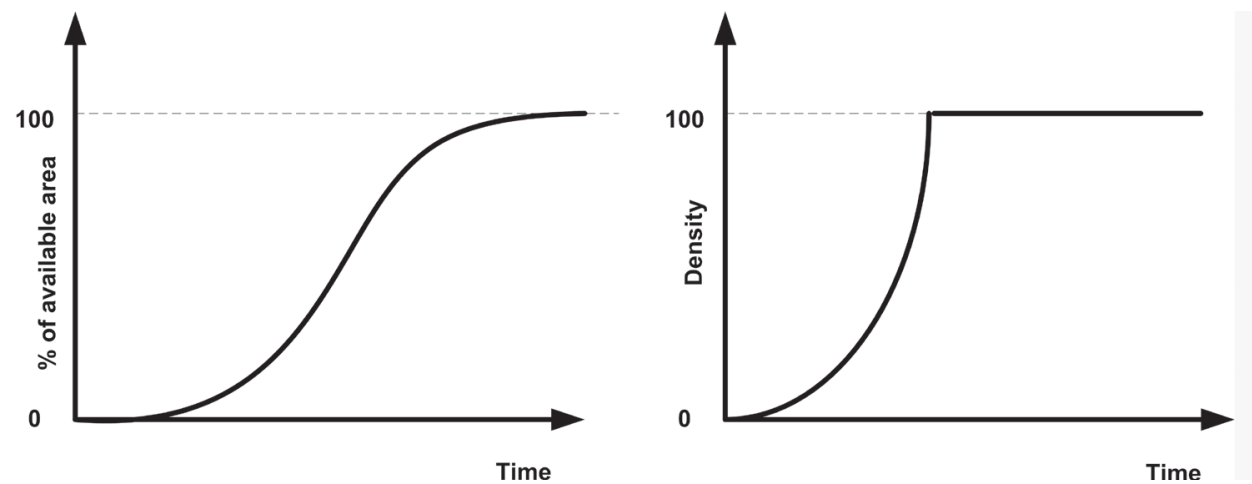

\begin{tabular}{|c|c|c|c|c|c|}
\hline Symbol & Parameter & $\begin{array}{c}\text { Old } \\
\text { value }^{1}\end{array}$ & $\begin{array}{c}\text { New } \\
\text { value }^{2}\end{array}$ & $\begin{array}{c}\text { Percentage } \\
\text { change }\end{array}$ & Units \\
\hline$p_{1}$ & Price of Pinus species & 7300 & 12555 & 72 & rand/hectare \\
\hline$p_{2}$ & Price of $A$. mearnsii & 1800 & 4089 & 127 & rand/hectare \\
\hline$q_{2}^{\mathrm{F}}$ & Accessibility coefficient $P$. pinaster fynbos & $1.2 \times 10^{-5}$ & $1.0 \times 10^{-4}$ & & $1 /($ hectare $\times$ year $)$ \\
\hline$q_{2}^{G}$ & Accessibility coefficient $P$. patula grassland & $1.1 \times 10^{-5}$ & $4.0 \times 10^{-3}$ & & $1 /($ hectare $\times$ year $)$ \\
\hline$q_{1}^{\mathrm{F}}$ & Accessibility coefficient $A$. mearnsii fynbos & $1.1 \times 10^{-4}$ & $2.0 \times 10^{-4}$ & & $1 /($ hectare $\times$ year $)$ \\
\hline$q_{1}^{G}$ & Accessibility coefficient $A$. mearnsii grassland & $1.0 \times 10^{-6}$ & $2.0 \times 10^{-4}$ & & $1 /($ hectare $\times$ year $)$ \\
\hline
\end{tabular}

Figure 4: The dynamic behaviour of (a) change in area invaded, and increase in density over time

Table 2: New values for model that reduce invasions to zero by 2025 
be performed to ensure consistency. Also, behaviour verification was conducted by comparing a plot of the model output with historical time series data. Good historical data on species spread were not available, so a conservative $5 \%$ growth in species area over time (Van Wilgen and Le Maitre 2013) was assumed (Figure 5). Although the model does not capture the intermediate values well in all cases, the long-term trend in the data is captured reasonably well. The model therefore provides an acceptable, although not perfect, replication of known behaviour of the system.

Structure verification tests were also conducted, and since the model is derived from the well-established literature on predator-prey interactions it is deemed adequate. Data from the study were also derived from the literature, and missing parameter values were obtained through optimisation. On the basis of these tests we conclude that the model is sufficiently robust to be used for simulation.

\section{Results}

In this section we consider the results of the simulation model, with the model calibrated with the historical data, on area invaded and control effort.

Three scenarios are considered:

1. Business as usual: clearing continues at existing levels (unit of measure = ha cleared].

2. Do nothing scenario: control effort proceeds from 1996 to 2014 (following Nkambule et al. 2017; Mudavanhu et al. 2017b), where after no clearing is undertaken.

3. VAP scenario: the price of VAPs increases by between $70 \%$ and $130 \%$, and accessibility to IAPs is improved (for example, through improved harvesting technologies). In our model, profitability drives the dynamics of clearing and therefore IAP spread, so it is crucial to consider the impact of accessibility and profitability on IAP spread.

\section{Business as usual}

Under business as usual, all species increase until at least 2025, which is the terminating period of the model (Figure 6).

\section{Do nothing scenario}

The do nothing scenario indicates the effect of ceasing clearing operations. The simulations indicate that clearing has had a small effect on IAP area, but not much (Figure 6) (note under this scenario that clearing is from 1996 and terminates in 2014). The implications of the scenario on values is discussed in a subsequent section.

\section{VAP scenario}

Using unpublished data from W. Stafford (personal communication) on the value of sales of timber and timber products and sales of roundwood per species and plantation areas per species, and deducting 60\% intermediate costs for wood products (Turpie et al. 2003), it is possible to estimate an approximate market value for pine timber (R12 $555 \mathrm{ha}^{-1}$ at 1996 prices) and wattle firewood (R4 089 ha $^{-1}$ at 1996 prices). These are coarse estimates based on national data and therefore do not consider local dynamics such as distance to market, wood quality, etc. The new values for the model are given in Table 2 .

Under the business as usual scenario, clearing levels are not sufficient to eliminate $A$. mearnsii or $P$. patula in the grassland biome. This is primarily due to the low accessibility coefficient of the wattle invasions. The low accessibility coefficient is a function of topography, primarily due to
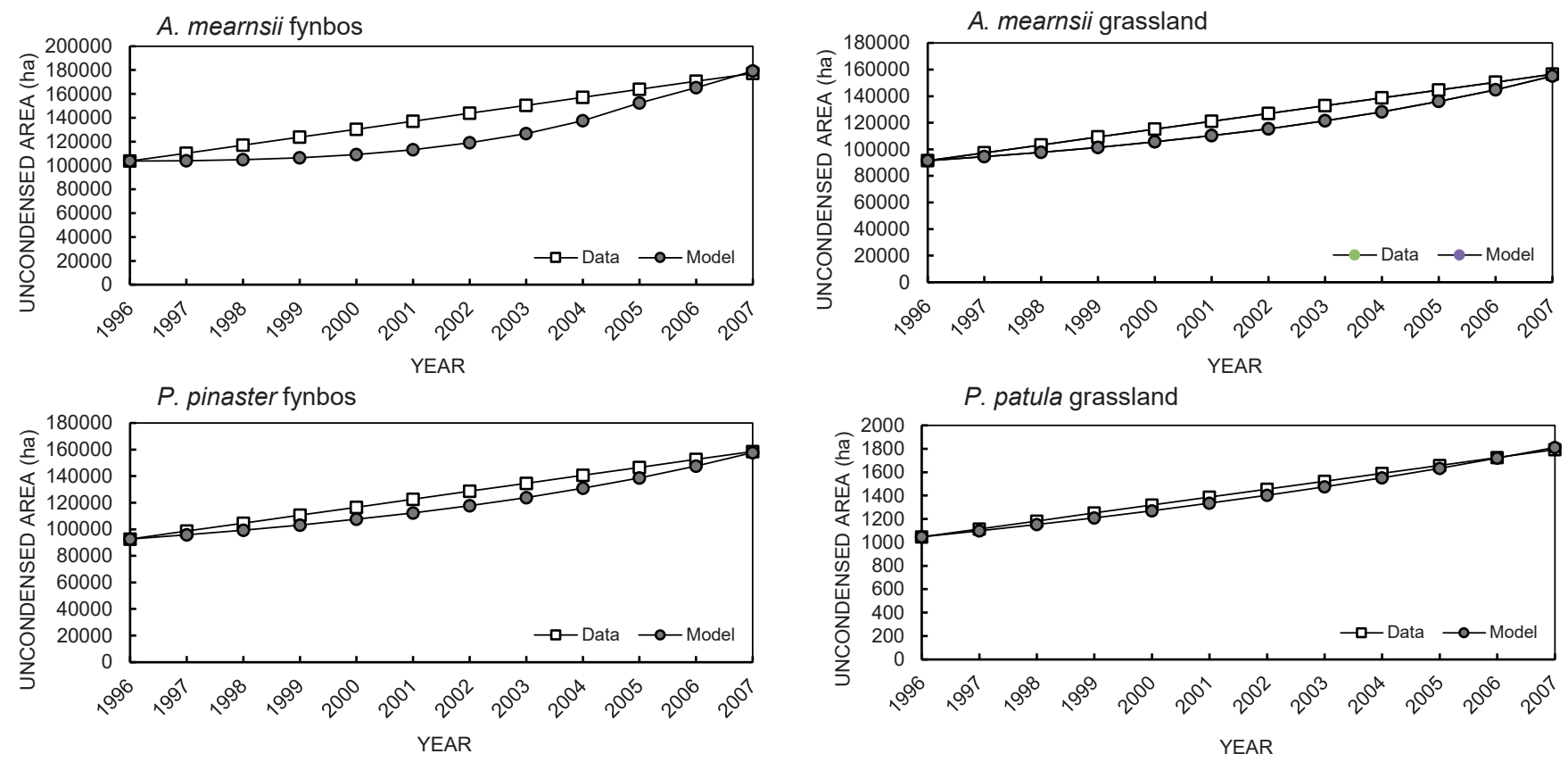

Figure 5: Invasive alien plant area (ha). The approach adopted by the study is to use optimisation to estimate the values of unknown parameters that provided the best fit with the historical data. 
A. mearnsii fynbos

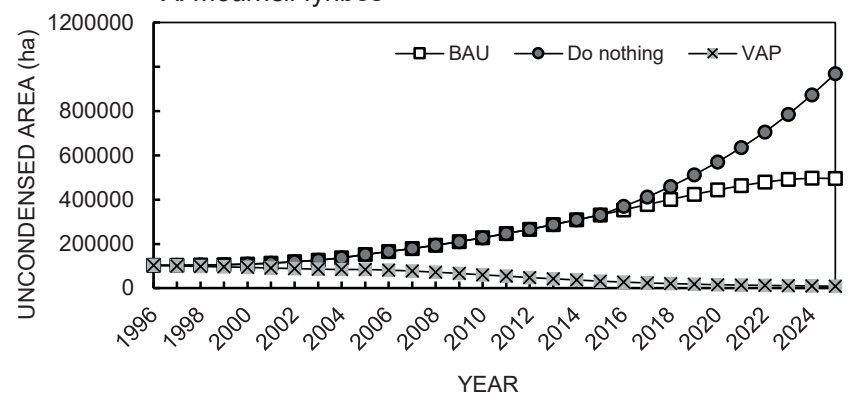

P. pinaster fynbos

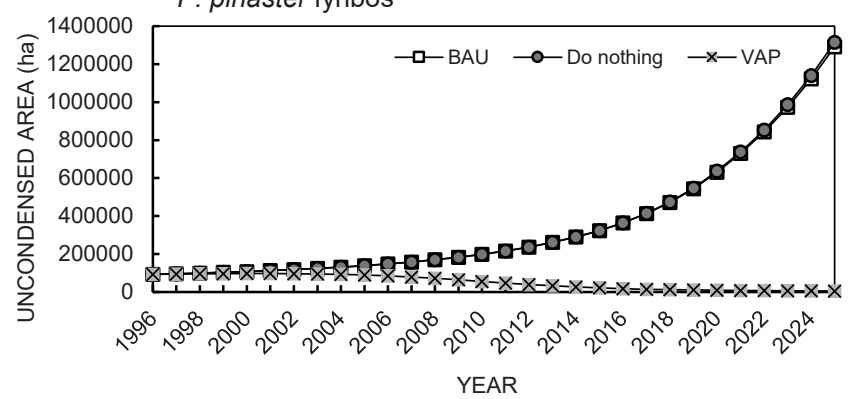

A. mearnsii grassland

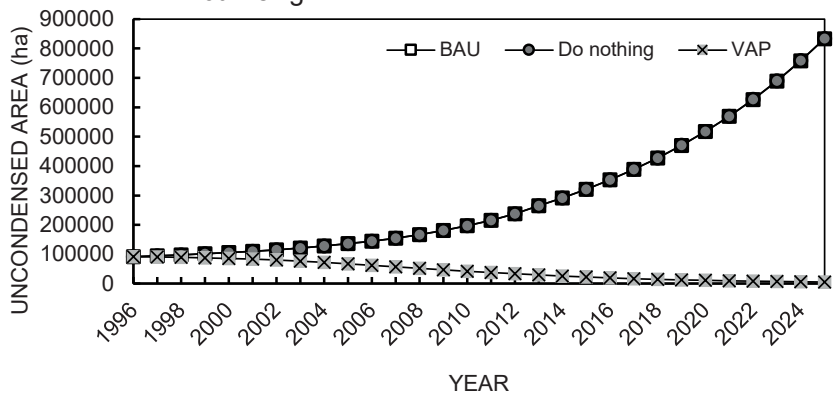

P. patula grassland

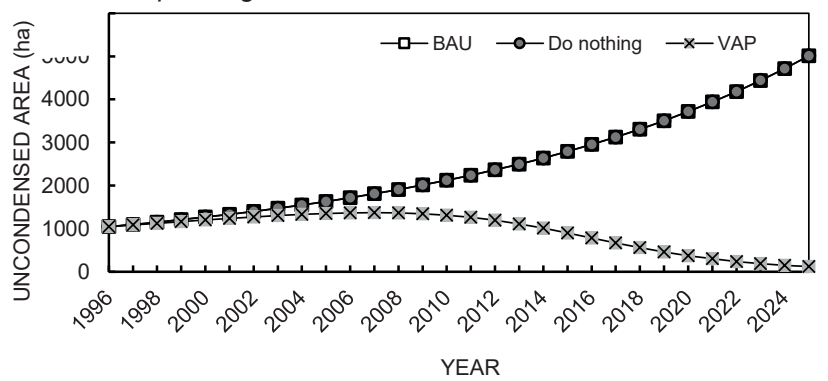

Figure 6: Three scenarios, and impact on IAP area (ha). Note: unless otherwise indicated, Business as usual and Do nothing overlap on the graph

the invasions being located mainly in or near riparian areas which are often in ravines or gullies or in rugged areas. Under the VAP scenario, however, the accessibility coefficient of all IAPs as well as the price of VAPs are increased to market related levels. The accessibility coefficient is increased through, for example, improved harvesting technologies. Figure 6 gives the results of model runs using these parameter values and shows declines in species spreads over time at least until the end of the model simulation.

\section{Nett present values}

Nett present values are estimated for the three scenarios and three species (Table 3 ). The do nothing scenario indicates societal losses for all three species modelled. The business as usual scenario indicates some societal benefit from clearing for $A$. mearnsii. This is consistent with the literature. De Wit et al. (2001) found that clearing wattle produced a nett benefit from clearing of US\$874 million at a national level, although this study includes many other benefits not included in our study. Also, the scope of our study was different, being for the moist grassland and fynbos regions only, and excluding low density stands. The VAP scenario produced the best societal values, which had the double dividend of also reducing IAP spread.

\section{Conclusions}

Our study finds that improving accessibility to invasive alien Pinus species and $A$. mearnsii in the grassland and fynbos biomes, as well as improving profitability from VAPs such as pine timber and wattle firewood is crucial to ensure that harvesting is profitable, and at the same time that these
Table 3: Nett present values (1996 R million) for the three species

\begin{tabular}{lccc}
\hline & $\begin{array}{c}\text { Scenario 1: } \\
\text { BAU }\end{array}$ & $\begin{array}{c}\text { Scenario 2: } \\
\text { Do nothing }\end{array}$ & $\begin{array}{c}\text { Scenario 3: } \\
\text { VAP }\end{array}$ \\
\hline P. patula & -0.107 & -0.095 & 2.708 \\
P. pinaster & -2.123 & -4.687 & 151.68 \\
A. mearnsii & 17.37 & -0.69 & 115.92 \\
\hline
\end{tabular}

Notes: Simulation from 1996 to 2025 (30 years). Discount rate 6\% following Conningarth Economists (2007).

invasive species are eradicated. This is the first study we know of that modelled IAP control as a predator-prey system, and which also includes accessibility in the model. The results show that accessibility, particularly in relation to harvesting technologies, is crucial in informing clearing efforts. Without this improvement, and without increases in the value of sales of timber products, there is insufficient incentive to clear these three species in the grassland and fynbos biomes.

Acknowledgements - The authors thank Department of Environmental Affairs: Natural Resource Management for the financial support, and South African Environmental Observation Network (SAEON) for hosting the project.

\section{ORCIDs}

Douglas J Crookes - https://orcid.org/0000-0001-9357-5396 James N Blignaut - https://orcid.org/0000-0001-7059-9010

David C Le Maitre - https://orcid.org/0000-0003-1037-6637 


\section{References}

Ballance A, Shackleton CM, Shackleton SE, Geach B, Crookes D, De Wit M, Evans J, Von Maltitz G, Willis C, Kelatwang S, Havemann J. 2001. Valuing South Africa's savannas: methodological issues. Southern African Forestry Journal 191: 43-52.

Bjørndal T, Conrad JM. 1987. The dynamics of an open access fishery. Canadian Journal of Economics 20: 74-85.

Blignaut J, Mander M, Schulze R, Horan M, Dickens C, Pringle K, Mavundla K, Mahlangu I, Wilson A, McKenzie M, McKean S. 2010. Restoring and managing natural capital towards fostering economic development: Evidence from the Drakensberg, South Africa. Ecological Economics 69: 1313-1323.

Conningarth Economists. 2007. A manual for cost benefit analysis in South Africa with specific reference to water resource development (2nd edn.). WRC Report No. TT 305/07. Pretoria: Water Research Commission.

Crookes DJ. 2016. Trading on extinction: an open access deterrence model for the South African abalone fishery. South African Journal of Science 112(3/4): 105-113.

Crookes DJ. 2017. Does a reduction in the price of rhino horn prevent poaching? Journal for Nature Conservation 39: 73-82.

Crookes DJ. 2018. Does the construction of a desalination plant necessarily imply that water tariffs will increase? A system dynamics analysis. Water Resources and Economics 21: 29-39.

Crookes DJ, Blignaut JN. 2016. Predator-prey analysis using system dynamics: an application to the steel industry. South African Journal of Economic and Management Sciences 19(5): 733-746.

Crookes DJ, Blignaut JN. 2019. Investing in natural capital and national security: A comparative review of restoration projects in South Africa. Heliyon 5: e01765. https://doi.org/10.1016/j. heliyon.2019.e01765.

Crookes D, Blignaut JN, de Wit MP, Esler K, Le Maitre D, Milton S, Mitchell S, Cloete J, de Abreu P, Fourie H, Gull K, Marx D, Mugido W, Ndhlovu T, Nowell M, Pauw M, Rebelo A. 2013. Dynamic modelling to assess economic viability and risk trade-offs for eight ecological restoration projects in a water-scarce developing country. Journal of Environmental Management 120: 138-147.

Cullis JDS, Görgens AHM, Marais C. 2007. A strategic study of the impact of invasive alien plants in the high rainfall catchments and riparian zones of South Africa on total surface water yield. Water SA 33(1): 35-42.

Dendrinos DS, Mullally H. 1981. Evolutionary patterns of urban populations. Geographical Analysis 13(4): 328-344

De Wit M, Crookes D, van Wilgen BW. 2001. Conflicts of interest in environmental management: Estimating the costs and benefits of a tree invasion. Biological Invasions 3: 167-178.

Drake JA, Mooney HA, di Castri F, Groves RH, Kruger FJ, Rejmanek M, Williamson M. (Eds.). 1988. Biological Invasions. A Global Perspective. Chichester: Wiley \& Sons.

Dye P, Versfeld D. 2007. Managing the hydrological impacts of South African plantation forests: An overview. Forest Ecology and Management 251: 121-128.

Fowler NL, Pease CM. 2010. Temporal variation in the carrying capacity of a perennial grass population. The American Naturalist 175(5): 504-512.

Gaertner M, Fisher JL, Sharma GP, Esler KJ. 2012. Insights into invasion and restoration ecology: Time to collaborate towards a holistic approach to tackle biological invasions. NeoBiota 12: 57-75.

Gaertner M, Biggs R, Te Beest M, Hui C, Molofsky J, Richardson DM. 2014. Invasive plants as drivers of regime shifts: identifying high-priority invaders that alter feedback relationships. Diversity and Distributions 20: 733-744.

Grimsrud KM, Chermak JM, Hansen J, Thacher JA, Krause
K. 2008. A two-agent dynamic model with an invasive weed diffusion externality: An application to Yellow Starthistle (Centaurea solstitialis L.) in New Mexico. Journal of Environmental Management 89(4): 322-335.

GTI. 2015. 2013-2014 South African National Land-Cover Dataset. Data User Report and MetaData. Version 05 (DEA Open Access). Pretoria: Geoterraimage.

Henderson L. 2001. Alien weeds and invasive plants. Plant Protection Research Institute Handbook No. 12. Pretoria: Agricultural Research Council.

Henderson L. 2007. Invasive, naturalized and casual alien plants in southern Africa: a summary based on the Southern African Plant Invaders Atlas (SAPIA). Bothalia 37: 215-248.

Hengeveld R. 1989. Dynamics of biological invasions. London: Chapman \& Hall.

Higgins SI, Turpie JK, Costanza R, Cowling RM, Le Maitre DC, Marais C, Midgley GF. 1997. An ecological economic simulation model of mountain fynbos ecosystems: dynamics, valuation and management. Ecological Economics 22: 155-169.

Hoffmann JH, Moran VC, Van Wilgen BW. 2011. Prospects for the biological control of invasive Pinus species (Pinaceae) in South Africa. African Entomology 19(2): 393-401.

IDC. 2011. Green jobs: estimating the employment potential of a growing green economy in South Africa. Johannesburg: IDC.

Kotzé JDF, Beukes BH, Van den Berg EC, Newby TS. 2010. National Invasive Alien Plant Survey. Report Number: GW/A/2010/21. Agricultural Research Council: Institute for Soil, Climate and Water, Pretoria.

Le Maitre D, Forsyth G, Dzikiti S, Gush M. 2013. Estimates of the impacts of invasive alien plants on water flows in South Africa. Report number: CSIR/NRE/ECO/ER/2013/0067/B. CSIR Natural Resources and the Environment, Stellenbosch.

Le Maitre DC, Forsyth GG, Dzikiti S, Gush MB. 2016. Estimates of the impacts of invasive alien plants on water flows in South Africa. Water SA 42(4): 659-672.

Le Maitre DC, van Wilgen BW, Gelderblom CM, Bailey C, Chapman RA, Nel JA. 2002. Invasive alien trees and water resources in South Africa: Case studies of the costs and benefits of management. Forest Ecology and Management 160: 143-159.

Marais C, Wannenburgh AM. 2008. Restoration of water resources (natural capital) through the clearing of invasive alien plants from riparian areas in South Africa - Costs and water benefits. South African Journal of Botany 74: 526-537.

McConnachie MM, van Wilgen BW, Richardson DM, Ferraro PJ, Forsyth AT. 2015. Estimating the effect of plantations on pine invasions in protected areas: a case study from South Africa. Journal of Applied Ecology 52: 110-118..

Moody ME, Mack RN. 1988. Controlling the spread of plant invasions: The importance of nascent foci. Journal of Applied Ecology 25: 1009-1021.

Moran VC, Hoffmann JH, Donnelly D, Zimmermann HG, Van Wilgen BW. 2000. Biological control of alien invasive pine trees (Pinus species) in South Africa. In: Spencer, NR (ed). Proceedings of the $X$ International Symposium on Biological Control of Weeds - July 4-14, 1999. Bozeman, MT, USA: Montana State University. pp 941-953.

Morokong T, Blignaut J, Nkambule NP, Mudavanhu S, Vundla T. 2016. Clearing invasive alien plants as a cost-effective strategy for water catchment management: The case of Olifants River catchment, South Africa. SAJEMS 195: 774-787.

Mucina L, Rutherford MC. 2006. The vegetation of South Africa, Lesotho and Swaziland. Strelitzia 19. Pretoria: South African National Biodiversity Institute.

Mudavanhu S, Blignaut J, Nkambule NP, Morokong T, Vundla T. 2016. A cost-benefit analysis of using the invasive Rooikrans trees (Acacia cyclops) as a biomass feedstock for electricity generation: A case study of the De hoop Nature reserve of 
the Western Cape Province of South Africa. SAJEMS 19(5): 788-813.

Mudavanhu S, Blignaut JN, Vink N, Crookes D, Nkambule N. 2017a. An economic analysis of different land-use options to assist in the control of the invasive Prosopis (Mesquite) tree. African Journal of Agricultural and Resource Economics 12(4): 366-411.

Mudavanhu S, Nkambule NP, Blignaut J, Vundla T, Morokong T. 2017b. A cost-benefit analysis of clearing invasive alien plants in the Berg River quaternary catchment of South Africa. African Journal of Agricultural and Resource Economics 12(4): 289-321.

Nel JL, Richardson DM, Rouget M, Mgidi T, Mdzeke N, Le Maitre DC, van Wilgen BW, Schonegevel L, Henderson L, Neser S. 2004. A proposed classification of invasive alien plant species in South Africa: towards prioritizing species and areas for management action. South African Journal of Science 100: 53-64.

Nkambule NP, Blignaut JN, Vundla TT, Morokong T, Mudavanhu S. 2017. The benefits and costs of clearing invasive alien plants in northern Zululand, South Africa. Ecosystem Services 27(B): 203-23.

Nyoka BI. 2003. Biosecurity in forestry: a case study on the status of invasive forest trees species in Southern Africa. Forest Biosecurity Working Paper FBS/1E. Forestry Department. Rome: FAO.

Orishimo I. 1987. An approach to urban dynamics. Geographical Analysis 19(3): 200-210.

Osunkoya OO, Othman FE, Kahar RS. 2005. Growth and competition between seedlings of an invasive plantation tree, Acacia mangium, and those of a native Borneo heath-forest species, Melastoma beccarianum. Ecological Research 20(2): 205-214.

Richardson DM, Macdonald IAW, Hoffmann JH, Henderson L. 1997. Alien plant invasions. In: Cowling RM, Richardson DM, Pierce SM. (eds), Vegetation of Southern Africa. Cambridge UK: Cambridge University Press. pp 535-570.

Rouget M, Richardson DM, Nel J, Le Maitre DC, Egoh B, Mgidi, T. 2004. Mapping the potential ranges of major plant invaders in South Africa, Lesotho and Swaziland using climatic suitability. Diversity and Distributions 10: 475-484.

Roura-Pascual N, Richardson DM, Krug R, Brown A, Chapman RA, Forsyth GG, Le Maitre DC, Robertson MP, Stafford L, van Wilgen BW, Wessels N. 2009. Ecology and management of alien plant invasions in South African fynbos: accommodating key complexities in objective decision-making. Biological Conservation 142: 1595-1604.
Shackleton CM, McGarry D, Fourie S, Gambiza J, Shackleton SE, Fabricius C. 2007 Assessing the Effects of Invasive Alien Species on Rural Livelihoods: Case Examples and a Framework from South Africa. Human Ecology 1: 113-127.

Swart J. 1990. A system dynamics approach to predator-prey modeling. System Dynamics Review 6(1): 94-99.

Swart J, Hearne JW. 1989. A mathematical model to analyze predation and competition problems in a sheep-farming region. System Dynamics Review 5(1): 35-50.

Turpie JK, Heydenrych BJ, Lamberth SJ. 2003. Economic value of terrestrial and marine biodiversity in the Cape Floristic Region: implications for defining effective and socially optimal conservation strategies. Biological Conservation 112: 233-251.

Turpie JK, Marais C, Blignaut JN. 2008. The Working for Water Programme: evolution of a payments for ecosystem services mechanism that addresses both poverty and ecosystem service delivery in South Africa. Ecological Economics 65: 788-798.

Van Wilgen BW, Le Maitre DC. 2013. Rates of spread in invasive alien plants in South Africa. Report CSIR/NRE/ECOS/ ER/2013/0107A. Natural Resources and the Environment, CSIR, Stellenbosch.

Van Wilgen BW, Reyers B, Le Maitre DC, Richardson DM, Schonegevel L. 2008. A biome-scale assessment of the impact of invasive alien plants on ecosystem services in South Africa. Journal of Environmental Management 89: 336-349.

Van Wilgen BW, Forsyth GG, Le Maitre DC, Wannenburgh A, Kotzé JDF, Van den Berg E, Henderson L. 2012. An assessment of the effectiveness of a large, national-scale invasive alien plant control strategy in South Africa. Biological Conservation 148(1): 28-38.

Versfeld DB, Le Maitre DC, Chapman RA. 1998. Alien invading plants and water resources in South Africa: a preliminary assessment. WRC Report No. TT99/98. Water Research Commission, Pretoria.

Vundla T, Blignaut JN, Crookes D. 2017. Aquatic weeds: To control or not to control. The case of the Midmar Dam, KwaZulu-Natal, South Africa. African Journal of Agricultural and Resource Economics 12(4): 412-429.

Vundla T, Nkambule NP, Blignaut JN, Morokong T, Mudavanhu S. 2016. The opportunity cost of not utilising the woody invasive alien plant species in the Kouga, Krom and Baviaans catchments in South Africa. SAJEMS 19(5): 814-830.

WWF. 2013. An introduction to South Africa's water source areas. Cape Town: WWF South Africa. 